\section{Influences of the Flagging}

on Thread Looping and Fabric Gathering.

By Junko Akashi, Junko Nishikawa, Mutsuo Okuno and Koji Matsumoto,

Textile Research Institute of Osaka Prefecture, Asahi-machi, Izumiohtsu City, Osaka .

Photographic pictures have been taken of "flagging" and "thread looping" of five kinds of fabrics to investigate how the flagging affects thread looping.

The pictures have shown that:

$\begin{array}{rlll}\text { 会 員 } & \text { 明 石 渟 子* } \\ & \text { 西 川 潤 子 } \\ \text { 奥 野 } & \text { 睦 夫 } \\ \text { 松 } & \text { 本 幸 } \text { 司 }\end{array}$

技術報告

\section{1. 緒言}

フラッギングとは縫製技術上の用語で, 最新縫製科学 ${ }^{1)}$ の用語集によれば，「一片の材料が押さえ金の下に あるときの動作，特に押さえ金の張りがゆるいために針 の上昇につれて材料が針について持上がるてとをいう. また，のど板の針孔が大きすぎるため材料が針について ’針孔の中へ押し下げられることを意味する.」と表現 されており，一般に“ぱたつき”ともいわれている。

筆者らは，ニットの縫製実験中，縫いにくい原因がフ ラッギングによるものではないかと思われる生地に出合 った. それは，ハイゲージのニットで密度が高く，一 見しなやかでありながら針貫通抵抗が大きい生地で，目 飛び, 縫縮みを起しした.

フラッギングについては, American Fabrics ${ }^{2)}$ に 「あまり大きな針板の針穴はフラッギングの原因となる. フラッギングはぴんとはられていない生地が, 針で針 板の下方へ引込まれるときに起こる．これはスナッギ ング (snagging) の原因となる.」と記載されている程 度である. このほか,, フラッギングという用語は使われ ていないが，シーム パッカリングと生地の厚さの関係 3) およびシーム パッカリングと針の形状の関係 ${ }^{4)}$ におい てフラッギングが関与してくるてとが書かれている.

そてで，縫製中の針系のループ形状およびフラッギン グを的確に把握し，フラッギングの影響によって起てる

* J. Akashi, Member. J. Nishikawa, M. Okuno, K. Matsumoto, 大阪府立繊維技術研究所
(1) A form of loop agrees well with a lemniscate in width and length, if no flaggings occur. from looping, and causes skipping stitches.

(3) An extreme flagging may also cause fabric gatherings, because the fabrics to be sewn is fed by the feed dog, being pulled up around the needle hole of the throat plate.

(Received March 6, 1978)

のではないか，と思われる目飛び，縫縮みとの関係につ いて考察する.

\section{2. 撮影および計算方法ならびに試料}

\section{1 撮影方法}

ミシン作動中のループ形状およびフラッギングの撮影 は，観察したい現象を光電式ピック アップで検出し， ての信号と同期してストロボ スコープを単発発光させ 写真撮影した．フラッギングの撮影装置の写真を図 1 に またブロックダイヤグラムを図 2 亿示す．以下，ての 概略を述べる. 図 2 に示すように，乏シン (A) のはず み車に観察したい現象の位置で信号を送ることができる ように反射テープ（スコッチライトテープ）（B）を 貼り, 反射テープと垂直に光電式ピック アップ $\left(\mathrm{C}_{1}\right)$ を置き，てれと接続してあるフォトエレクトリック シ ンクロアナライザ $\left(\mathrm{C}_{2}\right)$ とストロボ スコープ $\left(\mathrm{D}_{1}\right)$ と を接続する．ストロボ スコープのランプ ハウス $\left(\mathrm{D}_{2}\right)$ を適当な照射位置におき，てれと接続しているストロボ スコープとカメラ $(\mathrm{E})$ を接続しておく. ストロボス コープ $\left(\mathrm{D}_{1}, \mathrm{D}_{2}\right)$ はカメラのシャッタを 1 回押すと光電 式ピックアップで受けた信号と同期して 1 回のみ発光 する. したがって, ミシンの1ストローク中のどの位置 でシャッタを押しているかわからないので, シャッタ速 度は乏シンの 1 ストロークよりも遅い速度とした。ルー プ形状の撮影も上記とほぼ同樣であるが，異なる点は， カメラの位置が被写体に対し斜め上になることとストロ ボをミシンのベッドの下から照射したてとである.
(2) An extreme flagging prevents a sewing thread 


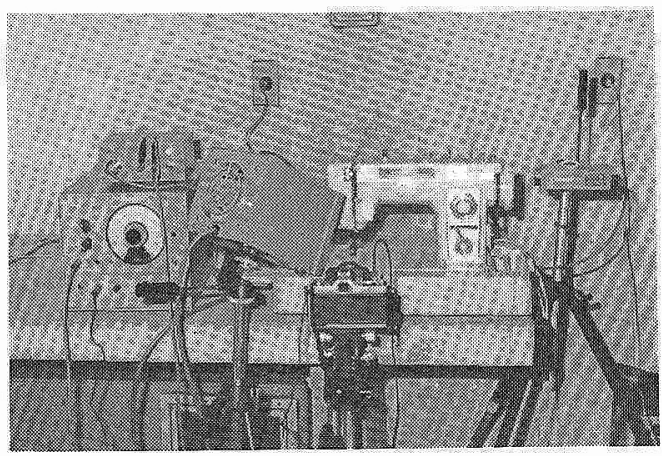

図1 フラッギング撮影装置

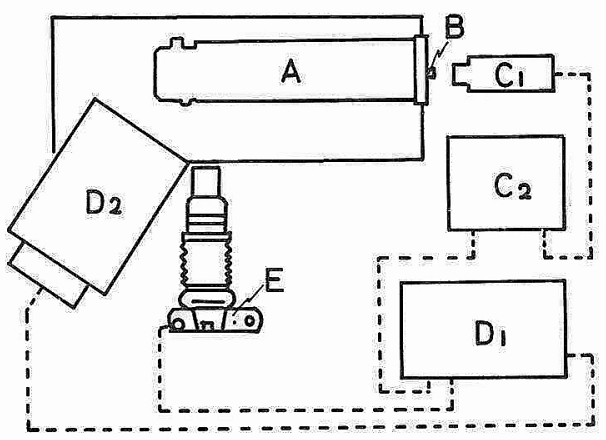

$\mathrm{A}: ミ \vee ン$

$\mathrm{B}$ : 反射テープ(スコッチライトテープ)

$\mathrm{C}_{1}$ : 光電式ピック アップ

$\mathrm{C}_{2}$ : フォトエレタトリックシンクロアナライザ

$\mathrm{D}_{1}:$ : ストボ スコープ

$\mathrm{D}_{2}$ : ストロボ スコープランプハ⿱ス

$\mathrm{E}:$ : カ

図2フラッギング撮影装置ブロック ダィヤグラム

撮影は次のような条件で暗室内で行なった。

(1) 使用フィルム；コダックトライX ASA400

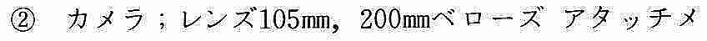
ント使用

閃光時間： $25 \mu \mathrm{sec}$

(3) 押さえ金 : 反射を防ぐため黒色塗料塗布

なお，縫糸のループ形状撮影にあたってはミシンの針 板および送り粜の台部分を一部削り，上からの撮影を可 能にした。

このループ形状撮影時のカメラのレンズ軸の方向を図 3 に示す。とのとき，後述のループの計算と合うょう に，ループの高さ方向を $x$ 軸，ループの幅方向を $y$ 軸, てれらに対して直角方向を $z$ 軸とし，レンズ軸のそれぞ れの軸とのなす角を $\alpha, \beta, \gamma$ とすると， $\alpha=45^{\circ}, \beta=58^{\circ}$, $r=62^{\circ}$ である.

\section{2 写真寸法から実寸を得る計算方法}

てのような位置で撮影したので，ループ形状の解析に あたっては，写真上の各部の長さから実の長さを計算す る必要がある。

との実験では視野角が小さい（望遠レンズ使用）の
で，視野角による写真上の図形の個所による寸法差を考 慮しないものとすると， $x, y, z$ 軸を斜め上方から撮影 して写し出された図形は、レンズ軸に平行な光線によっ て，レンズ軸に垂直な面（フィルム面に平行な面）に投 影された図形と同じと考えられる. まず, 図 3 に示すよ うにレンズ軸に添って線分 $O P$ (長さを $k$ とする) を とり, その方向余弦 $\cos \alpha, \cos \beta, \cos \gamma$ を $l, m, n$ とし, とれに垂直な面（フィルム面に平行な面）と $x, y, z$ 軸 とが交わる点をそれぞれ $A, B, C$ とすると，

$$
\frac{k}{\overline{O A}}=\cos \alpha \text { これから } \overline{O A}=\frac{k}{\cos \alpha}=\frac{k}{l}
$$

同様に $\overline{O B}=\frac{k}{m}, \overline{O C}=\frac{k}{n}$

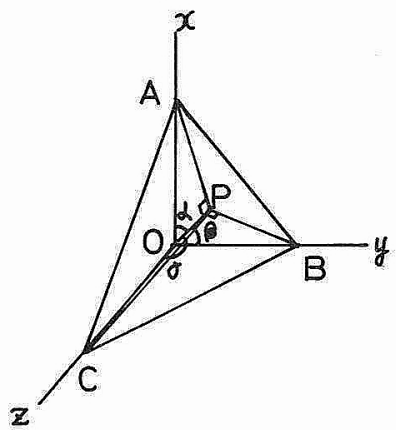

図3 レンズ軸方向とそれに垂直な面への投影図形 これら方面に投影されると $P A, P B, P C$ になりそれ ぞれ

$$
\overline{P A}=\frac{k \sqrt{1-l^{2}}}{l}, \overline{P B}=\frac{k \sqrt{1-m^{2}}}{m}, \overline{P C}=\frac{k \sqrt{1-n^{2}}}{n}
$$

となる。

したがって， $x, y, z$ 軸方向の線分の長さと投影され た線分の長さの比は，それぞれ次のようになる.

$$
\begin{aligned}
& \frac{\overline{O A}}{\overline{P A}}=\frac{1}{\sqrt{1-l^{2}}}=\frac{1}{\sin \alpha} \\
& \frac{\overline{O B}}{\overline{P B}}=\frac{1}{\sqrt{1-m^{2}}}=\frac{1}{\sin \beta} \\
& \overline{\overline{O C}}=\frac{1}{\sqrt{1-n^{2}}}=\frac{1}{\sin \gamma}
\end{aligned}
$$

つぎに，投影された $x$ 軸と $y$ 軸との交わる角度につい て考える. 実際の角度 $\angle A O B$ 办投影面では $\angle A P B$ 之 なるので，てれを求めてみる. $\triangle A P B$ について第2 余 弦公式から次式为成り立つ。

$$
\begin{aligned}
& \overline{A B^{2}}=\overline{P A^{2}}+\overline{P B^{2}}-2 \cdot \overline{P A} \cdot \overline{P B} \cdot \cos \angle A P B \\
& \text { 一方 } \overline{A B^{2}}=\overline{O A^{2}}+\overline{O B^{2}} \\
& \text { これらから }
\end{aligned}
$$

$$
\begin{aligned}
\cos \angle A P B & =\frac{\overline{P A}^{2}+\overline{P B}^{2}-\overline{O A}^{2}-\overline{O B}^{2}}{2 \cdot \overline{P A} \cdot \overline{P B}} \\
& =-\frac{l m}{\sqrt{\left(1-l^{2}\right)\left(1-m^{2}\right)}}=-\frac{\cos \alpha \cdot \cos \beta}{\sin \alpha \cdot \sin \beta}
\end{aligned}
$$

故に, 


$$
\angle A P B=\cos ^{-1}\left(-\frac{\cos \alpha \cdot \cos \beta}{\sin \alpha \cdot \sin \beta}\right)
$$

\section{3 試 料}

試料はニット 4 点, 比較用に織物 1 点およびゴム 1 点 を用いた．詳細は表 1 のとおりでニットはほぼ同一の厚 さの.ものを選んだ.

\section{4 維筡条件}

ミシンはループ形状撮影には側面がまのものを，フラ ッギング撮影には針位置がよくわかるように針の針穴が 正面を向いた正面がまのものを, 縫縮率の測定には工業 用乏シンをそれぞれ使用した。縫製条件を次に示す。

(1) ループ形状およびフラッギング撮影の場合

\section{ミシン :}

ループ形状撮影分 家庭用，ブラザー

HA2-B149, 810rpm

フラッギング撮影分——家庭用, ブラザー ZZ2-B706, 450rpm

ミシン針: HA H.1 \#11

そシン系:ナイロン66 \#50

(2) 縫縮率測定の場合

ミシン : 工業用, ジューキDDL-555-2-4 B, 押

さえ圧 $3 \mathrm{~kg}$, 送り歯高さ $0.6 \mathrm{~mm}$, 回転数 $3500 \mathrm{rpm}$

ミシン針: $\mathrm{DB} \times 1$ \#11

ミシン糸：ポリエステル フィラメント\#50

縫目長さ： $2 \mathrm{~mm} /$ 針

縫い方向：ウエール方向（たて方向）

縫縮率 : 上布，下布それぞれの縫縮率の平均值

\section{5 撮影時のミシンのタイミング}

写真撮影した之シンのタイそングは表 2 のとおりであ る. 針先位置は読取顕微鏡で読みとった。ミシン針位置 はJIS B 9004 家庭用ミシン用語（技術編）により，上死 点からの上軸回転角で表わした。

\section{3. 実験結果および考察}

\section{1 フラッギングが起こらない場合のループ形状}

ループ形成に係わる図を図 4 亿示す. 図 4 (a)は針が下 死点まで達したとき，図4(b)は かまの剣先が針と出合 うまで針が上昇したときの図である.

ループの形成は図 4 (a)に示すように 針が下死点に達 すると針系は最大量ひき出され，乙の時点で縫系にかか

表 1 試料

\begin{tabular}{|c|c|c|c|c|c|c|c|c|}
\hline \multirow[t]{2}{*}{$\begin{array}{l}\text { 試料 } \\
\text { No. }\end{array}$} & \multirow[t]{2}{*}{ 組 織 } & \multicolumn{2}{|c|}{$\begin{array}{c}\text { 密 度 } \\
(2.5 \mathrm{~cm})\end{array}$} & \multirow[t]{2}{*}{ 番手またはデニール } & \multirow[t]{2}{*}{ 組 } & \multirow[t]{2}{*}{ 成 } & \multirow{2}{*}{$\begin{array}{l}\text { 重 さ } \\
\left(\mathrm{g} / \mathrm{m}^{2}\right)\end{array}$} & \multirow{2}{*}{$\begin{array}{c}\text { 厚 さ } \\
(\mathrm{mm})\end{array}$} \\
\hline & & ウエール & コース & & & & & \\
\hline W & 平 織 & $\begin{array}{c}73 \\
\text { (たて系) }\end{array}$ & $\begin{array}{c}67 \\
\text { (よこ系) }\end{array}$ & $\begin{array}{cc}\text { たて糸 } 30 \mathrm{~s} \\
\text { よこ糸 } 36 \mathrm{~s}\end{array}$ & 綿 & & 100 & 0.30 \\
\hline \multirow{2}{*}{ K 1} & \multirow{2}{*}{$\begin{array}{l}\text { ハー フ } \\
\text { トリコット }\end{array}$} & \multirow{2}{*}{36} & \multirow{2}{*}{42} & フロント $75 \mathrm{~d} / 24 \mathrm{f}$ 加工糸 & ポリエステル & $100 \%$ & \multirow{2}{*}{95} & \multirow{2}{*}{0.49} \\
\hline & & & & バック $15 \mathrm{~d}$ 分絨系 & ポリエステル & $100 \%$ & & \\
\hline \multirow{2}{*}{ K 2} & \multirow{2}{*}{$\begin{array}{l}\text { ハ - フ } \\
\text { トリコット }\end{array}$} & \multirow{2}{*}{45} & \multirow{2}{*}{46} & フロント $70 \mathrm{~d} / 18 \mathrm{f}$ 加工糸 & ポリエステル & $100 \%$ & \multirow{2}{*}{112} & \multirow{2}{*}{0.36} \\
\hline & & & & バック $15 \mathrm{~d}$ 分繊糸 & ポリエステル & $100 \%$ & & \\
\hline \multirow[t]{2}{*}{ K 3} & \multirow[t]{2}{*}{ 両 面 } & \multirow[t]{2}{*}{54} & \multirow[t]{2}{*}{42} & 地 部 分 $50 \mathrm{~d} / 24 \mathrm{f}$ 加工糸 & $\begin{array}{l}\text { 複合繊維 } \\
\text { 芯部ポリエス } \\
\text { 鞘部ポリアマリア }\end{array}$ & $\begin{array}{l}\text { 系ポリマ } \\
\text { 系ポリマ }\end{array}$ & \multirow[t]{2}{*}{113} & \multirow[t]{2}{*}{0.52} \\
\hline & & & & 縞 部 分 $75 \mathrm{~d} / 24 \mathrm{f}$ 加工糸 & ポリエステル & $100 \%$ & & \\
\hline K 4 & 両 面 & 58 & 41 & $60 \mathrm{~d} / 20 \mathrm{f}$ & ナイロン & $100 \%$ & 134 & 0.49 \\
\hline G & \multicolumn{8}{|c|}{ ミューレン形破裂試験機の低圧用ゴム } \\
\hline
\end{tabular}

表 2 写真撮影時のミシン各部の位置

\begin{tabular}{|c|c|c|c|c|c|}
\hline & \multicolumn{2}{|c|}{$\begin{array}{l}\text { ブ ラ ザー } \\
\text { H A 2- B } 149\end{array}$} & \multicolumn{2}{|c|}{$\begin{array}{l}\text { ブ ラ ザー } \\
\text { Z Z 2-B } 706\end{array}$} & \multirow{2}{*}{$\begin{array}{r}\begin{array}{c}\text { ジューキ } \\
\text { D D L - 555 } \\
-2-4 \text { B }\end{array} \\
\text { 上軸回転角 }\end{array}$} \\
\hline & 上軸回転角 & $\begin{array}{l}\text { 下死点から } \\
\text { の針先位置 }\end{array}$ & 上軸回転角 & $\begin{array}{l}\text { 下死点から } \\
\text { の針先位置 }\end{array}$ & \\
\hline 針と剣先の出合う点 & $202^{\circ}$ & $2.0 \mathrm{~mm}$ & $210^{\circ}$ & $2.3 \mathrm{~mm}$ & \\
\hline $\begin{array}{l}\text { フラッギングが最高とな } \\
\text { る位置 (試料K } 4 \text { の場合) }\end{array}$ & & & $250^{\circ}$ & $14.2 \mathrm{~mm}$ & \\
\hline $\begin{array}{l}\text { 送り歯が針板面より上に } \\
\text { なる位置 }\end{array}$ & $290^{\circ}$ & & $270^{\circ}$ & & $310^{\circ}$ \\
\hline
\end{tabular}




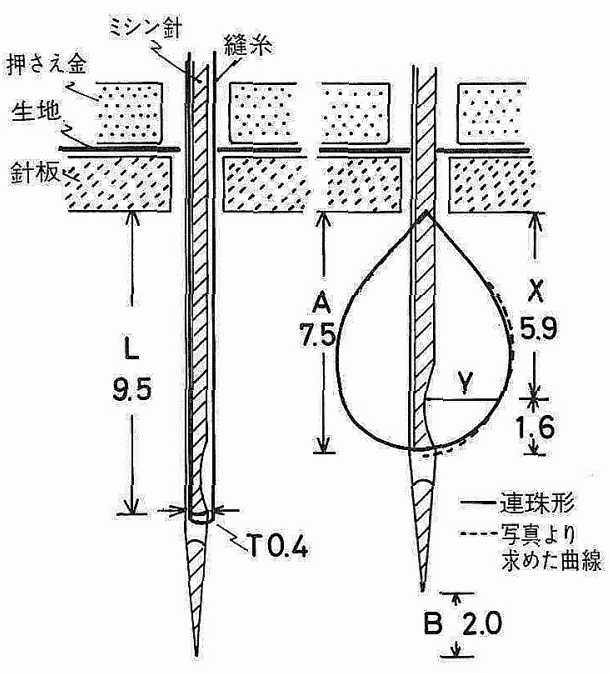

(a) 針が下死点の時 (b)かの㓣先が針と出合 万時

四4 フララッギングが起こらない場合のループ形成 っているテンションがなくなり，図4(b)のように縫系は 針の上杽に伴い針上昇分たるみループか形成される。

ループ形状の良否を知るために，ループのモデルを諘 えた。

撮影した写真（後揭の図 9)のうら一番大きなループ

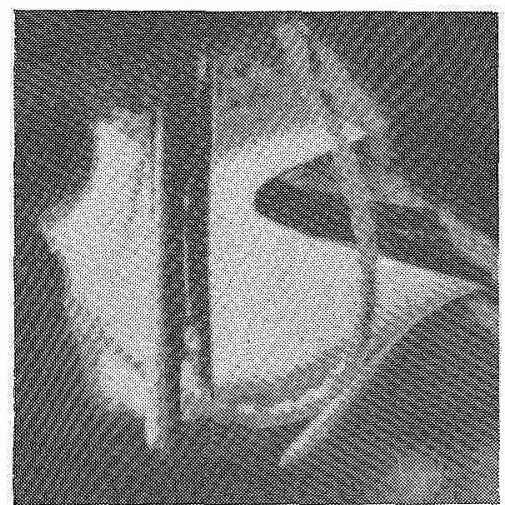

図５フフラッ゙ングが起こらない場合のループ形状 をもつ試料Wの写真（図 5) のループを式(1)，(2)，(4)を 用いて換算し正面図にしたループ形状を図 4 (b)に破線て 示す。との形状は連珠形 (lemniscate) と似ていたのて ループ形状を連珠形と考える。

連珠形の半分を極座標で表わせばと式のようになる。 $r=a \sqrt{\cos 2 \theta}^{5)}$

$$
\left(a>0,-\frac{\pi}{4} \leqq \theta \leqq \frac{\pi}{4}\right)
$$

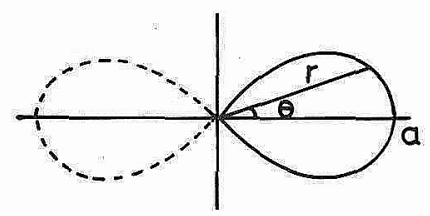

困 6 連珠形
一方，連珠形の $1 / 4$ 周長 $l \quad\left(0 \leqq \theta \leqq \frac{\pi}{4}\right)$ は次式で表わ される。

$$
\begin{aligned}
& l=\int_{0}^{\frac{\pi}{4}} \sqrt{r^{2}+\left(\frac{d r}{d \theta}\right)^{2}} d \theta \\
& =a \int_{0}^{\frac{\pi}{4}} \frac{d \theta}{\sqrt{1-2 \sin ^{2} \theta}}
\end{aligned}
$$

$\int_{0}^{\frac{\pi}{2}}-\frac{d t}{\sqrt{1-\frac{1}{2} \sin ^{2} t}}$ は第 1 種完全棈債分て数表 ${ }^{6)}$ か 51.854である.したがって，

$l=1.31 a$

となる。

次に，連珠形の $x$ の值に対して $y$ の值を求めるために 直交座標で表わせば,

$$
\left.\left(x^{2}+y^{2}\right)^{2}=a^{2}\left(x^{2}-y^{2}\right) \quad 5\right)
$$

これから

$$
\begin{aligned}
& y^{2}=\frac{-\left(2 x^{2}+a^{2}\right)+\sqrt{a^{2}\left(8 x^{2}+a^{2}\right)}}{2} \\
& y=\sqrt{\frac{\text { (正の值のみをとる.) }}{\frac{-\left(2 x^{2}+a^{2}\right)+\sqrt{a^{2}\left(8 x^{2}+a^{2}\right)}}{2}}}
\end{aligned}
$$

となる.

ここで, 図4のループ形成にかかわるミ゙ンン針の動き の実測值抢よひ戍 5 の写真上の寸法からループ形状につ いて考えてみる。

図 4 (a)，(b)に示すように，針か下死点に達したときの 針板下端から針の針穴上端までの寸法を $L$ ，下死点から $2 \mathrm{~mm}$ 上开時の針板下端からら針の針穴上端までの寸法（以 下ループ高さと(ら)をA，針とかまの剣先との出合 引高さ (針の針穴上端より $1.6 \mathrm{~mm}^{7}$ ) 上) における針とル ープとの間隔 (以下ループ幅という) をY，針の針穴 上端部分の針の厚さを $T$ とする．さらに縫糸は完全に生 地で把持され，伸縮性がなくぞシン針の長みぞの影響 はないものとしておく.

まずループ形状を描く.(5)式の $a$ にシン針の動きか ら求めたループ高さ $A=7.5 \mathrm{~mm}$ 入れて作図したのか図 4 (b)に续線で描いたループである，乙れは先に写真から 求めた破線のループと形状か活致する.

次にループ長とループ高さの比を求める。ループ長の $1 / 2$ は $L+T / 2=9.7 \mathrm{~mm}$ であり, $A=7.5 \mathrm{~mm}$ であるから， ループ長とループ高さの比は

$(L+T / 2) / A=9.7 / 7.5=1.29$

となり，(7)式の $/ / a=1.31$ と近似する.

また，図 5 のループ形状写真から実際のループ幅を求 
める. まず, ループ幅を測定するにあたり，針と剣先と の出合う位置をきめる。この位置は実際では針の針穴上 端より $1.6 \mathrm{~mm}$ 上であるので，フィルム面では(1)式より $1.6 \cdot \sin 45^{\circ}=1.13(\mathrm{~mm})$ となる。 また，フィルム面に現 われた $x$ 軸と $y$ 軸との交わる角度 $\theta$ は(4)式より $\theta=\cos ^{-1}(-\cos \alpha \cdot \cos \beta / \sin \alpha \cdot \sin \beta)=128^{\circ}$ となる.な お，ての角度については， $x$ 軸， $y$ 軸を描いた図をルー プ形状撮影の場合と同方向から撮影し，その写真上の角 度が(4)式から求めた角度と近似することで確認した。と のように，写真上の剣先と出合う点およびループ愊を測 る方向をきめて測定した図 5 (試料W) の写真上のルー プ幅は2.0mmであるので，てれから実際の幅 $Y は(2)$ 式よ り $Y=2.0 / \sin 58^{\circ}=2.35 \mathrm{~mm}$ となる. 一方, 乏シンの機械 的な動きから(8)式によりループ幅を求める. (8)式の $a$, $x$ に図 4 (b)の $A=7.5 \mathrm{~mm} X=5.9 \mathrm{~mm}$ をそれぞれ入れて計 算すると， $y=2.38 \mathrm{~mm}$ となり, 連珠形として求めたて の值と先に写真から求めた值とがほぼ一敨する.

以上のように，フラッギングが起きずに理想的なルー プができた場合には, 写真から求めたループ形状，ミシ ン針の動きから求めたループ長とループ高さの比, 写真 から求めたループ幅が，連珠形の場合とそれぞれ一敨し t.

\section{2 フラッギングが起こった場合のループ長}

フラッギングの起こった場合のループ長について図 7

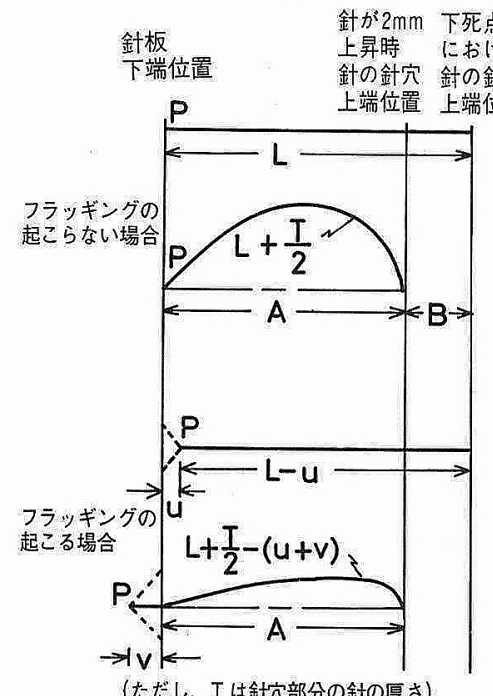

図 7 フラッギングの起こる場合のループ形成

のように考える. 前にも述べたが，縫系は生地によって 針板上端で把持されるので，ての点からループ形状を考 えるべきだが，縫糸は針板の針穴を針とほほ平行にとお り，針板下端からループができるので，とてをループの 始点 $P$ として考光る.

まず，ひき込みフラッギングで点 $P$ と針の針穴上端間 は $L-u$ となる。さらにひき上げフラッギングでvひ
き上げられるとループ長は $(L+T / 2)-(u+v)$ となる。 $(u+v)$ がB (剣先と出合い時における不死点からの針 の上昇分）の值に近づくと十分なループ形成が望めなく なることか推察される.

\section{3 フラッギングとループ形成}

フラッギングが起とる場合と起しらない場合の典型的 な例を図 8 に示す. 図8(b)はほぼ押さえ金の厚み分 $(2.1 \mathrm{~mm})$ 生地がフラッギングでひき上げられており，几 一プがほとんどできていないととがわかる.

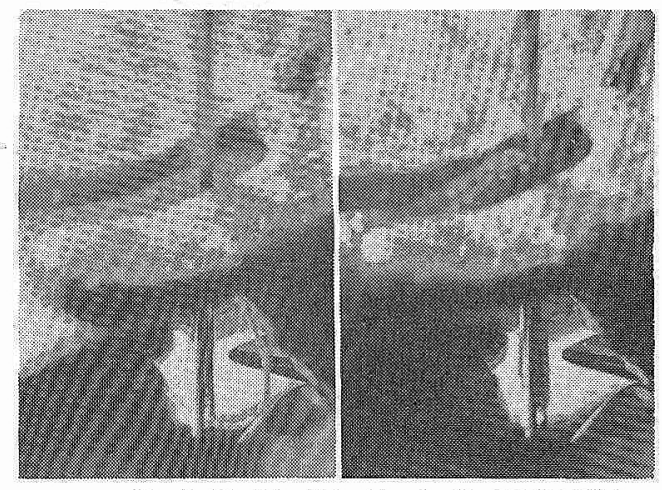

(a)フラッギングの起こらない場合 (b)フラッギングの起こる場合 図8フラッギングとループ形状

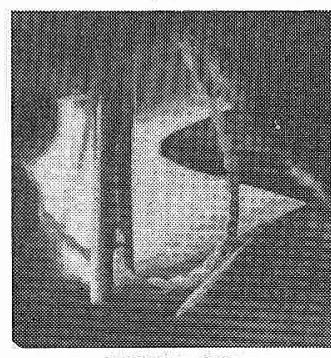

試料No. W

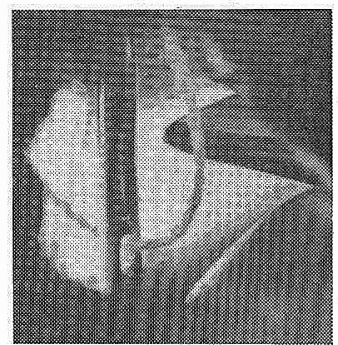

K 2

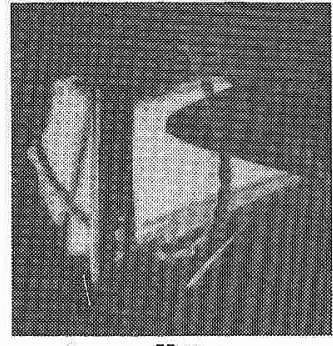

K 1

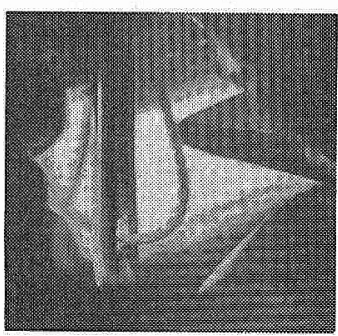

K 3

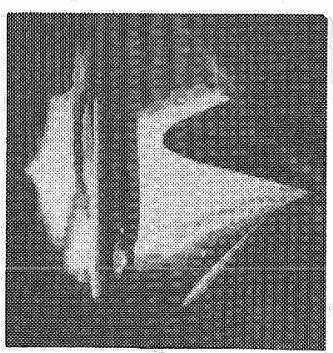

K 4

図9 各種試料縫製時のループ形状 
こてで各種生地の縫製中におけるループ形状について 述べる。上軸回転角 $202^{\circ}$ (かまの剣先が針糸をすくう寸 前) におけるループ形状写真を図 9 に示す. 図 9 から試 料Wはループが大きくくくみ，縫いにくく目飛びを起 てしやすい試料K 4 はほとんどループを形成していない てとがわかる. 武料K 4 においては, ループは短みぞ側 に出ないで，長みぞ側に小さいながら出ているのがみら れる.

フラッギングがループ形状に与える影響をみるため， フラッギング高さを写真により求めた．ての高さについ ては，3.2で述へたように，下死点におけるひき込みフ ラッギング高さ $u$ と軸回転角 $202^{\circ}$ におけるひき上げフ ラッギング高さvをそれぞれ測定し，それらを加えた值 をもってフラッギング高さとすべきであるが，写真撮影 の可能なひき上げフラッギングで予備実験の結果，大き 以值を示す上軸回転角 $250^{\circ}$ で撮影し，その高さを測定し た. ての理由は，202ではフラッギングはまだ小さく て，縫製時の布の波うちでフラッギング高さか測定しに くいととと，試料間の比較ができにくいととによる，1 針どとのフラッギングか撮れるようにミシン糸をかけず に縫製し測定した. 各種生地のフラッギングの写真を図 10に示す。ループがきれいに形成されている生地はフラ ッギングか低い。また，陚料K 4 はゴムと同じぐらいの

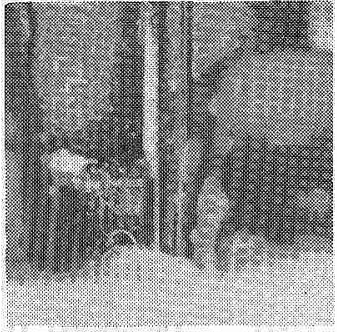

試料No. W

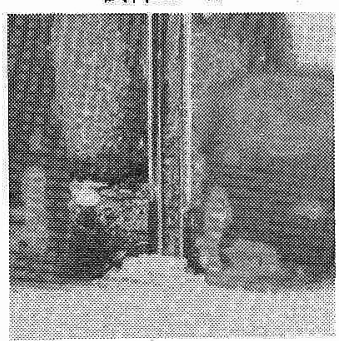

K 2

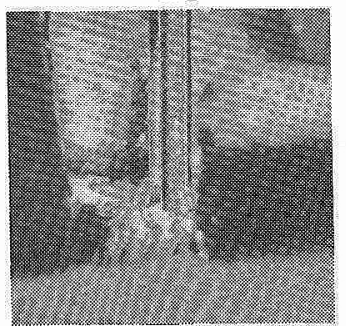

K 4

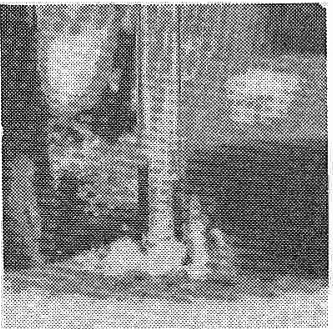

K 1

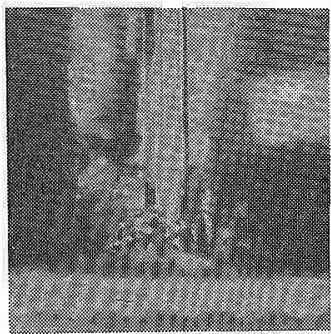

K 3

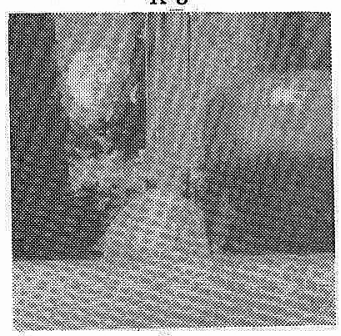

G
図10 各種試料糸なし運転時のフラッギング形状
フラッギングか起てっているてとがわかる.

図10から求めたフラッギング高さと, 図 9 から式(1),

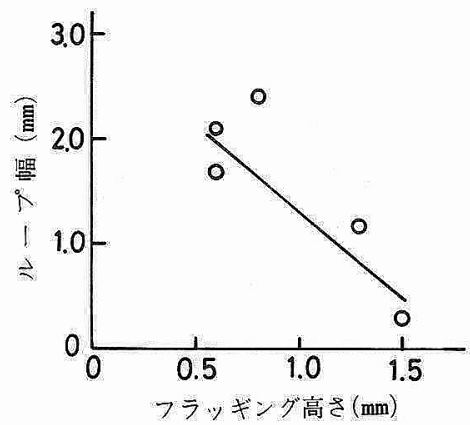

図11 フラッギング高さとループ幅の関係

(2)，(4)により補正したループ幅との関係を求めると， 図11のようになり,フラッギングが大きくなるとループ幅 が小さくなるとと，さらにループがほとんどできない と，かまの剣先がループをすくうのがむずかしくなり目 飛びにつながるととがわかる。

\section{4 フラッギングと縫縮み}

縫縮みが異常に大きくなる原因がフラッギングにある のではないが思われる場合があったので，フラッギン グの一番大きく出た試料K 4 亿つて上軸回転角を変え 写真撮影した. 比較用として試料Wについても写した。 なお， $310^{\circ}$ では家庭用々 ンンの場合フラッギングか湿著 でなかったので， $310^{\circ}$ の写真のみ工業用そンンで最影し たものである。

結果を図12に示す。試料 K 4 は, 送り歯が針板よりも上 にあがりかけ点 $270^{\circ}$ (ZZ2-B7060場合), $290^{\circ}$ ( $\mathrm{H}$

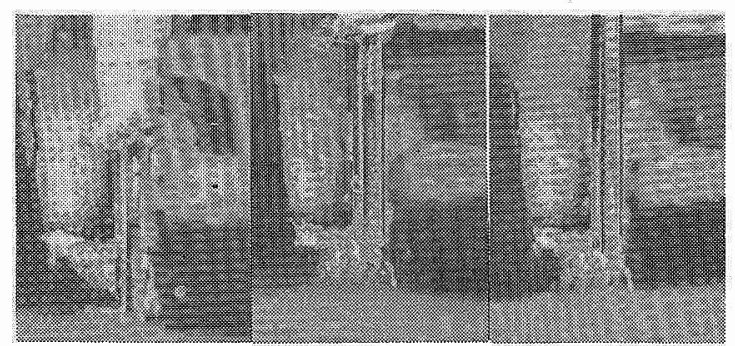

$$
\text { 上軘回転角 } 210^{\circ} \quad 230^{\circ} \quad 250^{\circ}
$$

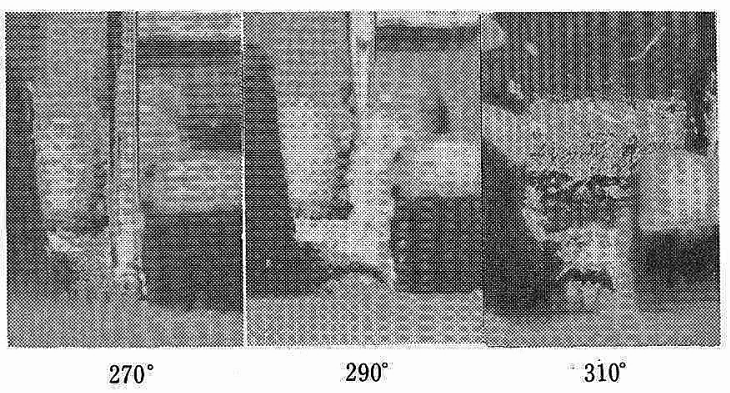

（a）試料K 4 の場合 

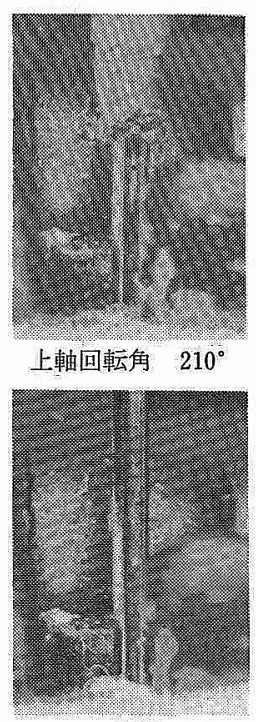

$250^{\circ}$

(b) 試料Wの場合

図12 位相の変化とフラッギング

A2-B1490場合)，310 (DDL-555-2-4B の場合) においても，なおもフラッギングかみられた。 とのとと は,フラッギングしている状態の生地を送り歯で送るこ とを意味し，フラッギングが縫縮みに関係するととがわ かる.

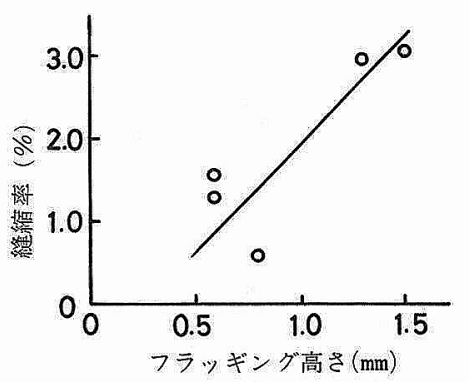

図13 フラッギング高さと縫縮率の関係

そしで，工業用ミシンで縫製したときの縫縮率を求 め,てれとフラッギング高さとの関係を図13に示した。 図13から，フラッギングは縫縮みに関係するととがわか st.

以上考察してきたが，この観点からのフラッギング防 止策については，次のようなものか溌表されている.

(1) ひき込みフラッギングを小さくするため，針穴の

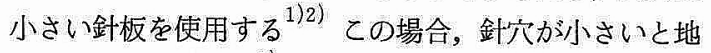
糸切れが起りやすい゙ので, 地系切れとの兼ね合いを考 える必要がある.

(2) ひき上げフラッギングを小さくするため，押さえ 金のスリット部分を小さくした押さえ金を使用する。と

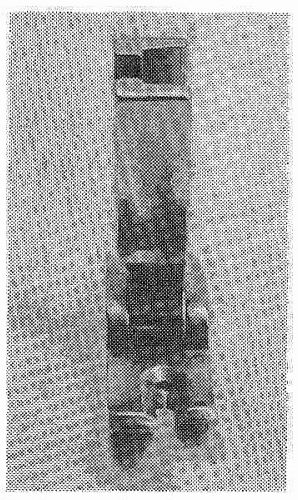

図14 ニット用押さえ金

のようにニット用に改良された押さえ金の一例 ${ }^{9)}$ を図14 に示す.

(3) ひき上げフラッギングで縫糸が生地につられて持 上げられるのを減少させるため，長みぞを深くえぐり目 飛び対策を講した家庭用々シン針 $\mathrm{HA} \times 1 \mathrm{KN}^{10)}$ があ る.

\section{4. 結言}

(1) フラッギングの起こらない場合のループは，形状， ループ長およびループ幅において連珠形とよく一致する (ただし，ナイロン66縫糸使用).

(2) フラッギングは々シンの機械的条件や縫糸等の縫製 条件が同一なら，生地によって大きさがちがう。

(3）大きなフラッギングはループの形成を妨げ，目飛び につながる.

(4) 大きなフラッギングは生地を針板の針穴周辺にひっ ぱり上げた状態で送り歯で送るので，縫縮みの原因とな ることがある。

おわりに，本研究遂行にあたり，こ協力いただいた当 所増田敏男研究員に深謝します。

\section{文献}

1) 田中道一; 最新㖓製科学, p.354, 日本緎維製品消費科学 会

2) American Fabrics, No.81, winter p. $74 \sim 75$ (1968)

3) 北田総雄: 最新縫製科学, p.140, 日本繊維製品消費科学会

4) 北田総雄; 同上 p.151

5）たとえば森口繁一ほか; 数学公式 I, p.289, 岩波全書 (1965)

6) たとえば岩波数学辞典, p.973 (1973)

7) 平松詮曹; 縫製事典 75, p.591, 繊維研究会

8) 池上夏樹ほか; 緎機誌，31, P105 (1978)

9）工業々シン用スキセイアタッチメンッ’ 76 , スキセイ工業 (株)

10）江口龍彦; 婦人子供乳児服製造技術短期研修講座講演内容 (1978. 2.7)

(昭和53年 3 月 6 日受理) 